\title{
PENERAPAN PENDEKATAN PROBLEM POSING PEMBELAJARAN MATEMATIKA DI KELAS VIII A SMPN 2 TAMAN
}

\author{
Anna Wahyu Hidayah \\ (SMP Negeri 2 Taman) \\ annawahyu694@gmail.com
}

\begin{abstract}
This research in the wake of the fact it can be said that the rapid technological development wasbased on the development of mathematics, math has been taught right from kindergarten up of a higher level.To print a future thinker with math experts needed for effective learning and efficientso that teachers should be able to select appropriate learning for students. formulation of the problem in this research is" how completeness of student learning outcomes, level of creative thinking abilitiesand the students' response to learning Problem Posing?" the purpose of this study was to describeclassically completeness of student learning outcome, level of creative thinking abilitiesand the students, and the response given students after learning Problem Posing.In this study to measure student mastery gained from achievement test(THB), to determine the level of students' creative thinking abilities(TKBKS) taken from the test results correlated learningwith components of creative thinkingthat is fluency, flexibility, originility, dan elaborationand to evaluate the response of the students was obtained from questionnaires source data from this study is the class VIII A SMPN 2 Taman. Data obtained from this study are as followsz: from the results THB stated that in the classical completeness of $85,29 \%$,as much as $67 \%$ students occupied TKBKS levelfour (very creative) and the students' response to the statement of learning Problem Posing have an average maximum of 3,51that is

" I feel Problem Posing learning model is useful for learning mathematics". From the above it can be concluded that the study results in the classical mastery learning Students Creative Thinking Ability level the student is able to be in a position TKBS 4 ( very creative ), students can be said to be a positive response.
\end{abstract}

Keywords: Creative thinking, level of creative thinking, fluency, flexibility, originility, elaboration,

\section{Problem Posing}

\section{PENDAHULUAN}

Perkembangan teknologi (IPTEK) saat ini telah berkembang dengan pesat. Hal ini telah mengantar masyarakat memasuki era global. Dapat dikatakan bahwa perkembangan teknologi dilandasi oleh perkembangan matematika dan untuk mencetak penemu - penemu ataupun pemikir di masa depan di perlukan penguasaan matematika

Salah satu upaya yang dapat dilakukan adalah melelui peningkatan kwalitas pendidikan yang berfokus pada pengembangan kemampuan. Undang - undang sisdiknas No. 20 Tahun 2003 dalam martinis Yamin (2013: 71) menyatakan bahwa tujuan pendidikan nasional adalah mengembangkan potensi peserta didik menjadi orang yang beriman dan bertaqwa kepada Tuhan Yang Maha Esa, berakhlak mulia, berilmu, sehat, cakap, kreatif, mandiri dan menjadikan warga yang demokratis. Berdasarkan peraturan tersebut, terlihat bahwa pengembangan kemampuan berpikir kreatif di dalam 
pendididkan merupakan aspek yang sangat penting kaitanya dengan pembentukan peserta didik.

Kemampuan berpikir kreatif diperlukan untuk mengelola dan memanfaatkan informasi untuk bertahan hidup pada kondisi yang selalu berubah, tidak pasti dan kompetitif. Oleh karena itu diharapkan guru lebih jeli lagi dalam memilih pembelajran yang tepat di kelas.

Salah satu yang dianggap dapat mengembangkan kemampuan berpikir kreatif siswaa dalah penerapan pendekatan Problem Posing pada pembelajaran. oleh karena itu penulis tertarik untuk meneliti tentang "Penerapan Pendekatan Problem Posing Dalam Pembelajaran Problem Matematika di kelas VIII A SMPN 2 TAMAN".

Melihat paparan di atas, peneliti ingin menjawab permasalahan Bagaimana ketuntasan klasikal hasil belajar siswa, Tingkat Kemampuan Berpikir Kreatif Siswa, dan respon siswa terhadap pelaksanaan pembelajaran matematika materi menyelesaikan masalah sehari - hari dengan menggunakan teorema pytagoras dengan menggunakan pendekatan Problem Posing (Pengajuan Soal) di kelas VIII A di SMPN 2 Taman? Yang hasilnya di harapkan dapat bermanfaat khususnya bagi guru Matematika sebagai wacana dalam upaya mengdakan fariasi pembelajran di kelas.Dengan demikian. Penelitian ni bertujuan untuk mendeskrepsikan Ketuntasan klasikal hasil belajar siswa, Tingkat Kemampuan Berpikir Kreatif Siswa, dan respon siswa terhadap pelaksanaan pembelajaran matematika dengan menggunakan pendekatan Problem Posing (Pengajuan Soal) di kelas VIII A SMPN 2 Taman.

\section{METODE PENELITIAN}

Penelitian ini merupakan penelitian kualitatif, yaitu mendeskripsikan tentang pembelajaran dengan pendekatan Problem Posing terhadap kemampuan berfikir kreatif siswa.

Dalam Penelitian ini penulis mendeskripsikan mengenai indikator - indikator, di antaranya adalah Hasil Belajar Siswa, Tingkat Keampuan Berpikir Kreatif Siswa dan Respon Siswa
Data diperoleh dari siswa SMPN 2 Taman kelas VIII A yang berjumlah 34 dengan rincian siswa laki -laki berjumlah sebanyak 15 siswa dan perempuan berjumlah 19 anak. Adapun teknis pengumpulan data yang dilakukan oleh peneliti adalah metode tes untuk mengetahui ketuntsan secara klasikal hasil belajar dan Tingkat Kemampuan Berpikir Kreatif Siswa (TKBKS) serta metode angket untuk mengetahui respon siswa

Ada beberapa jenis instrumen yang digunakan dalam penelitian, yaitu Tes dan Angket atau Kuesioner (Questionnaires). Analisis Tes Hasil Belajar Hasil belajar siswa ditentukan berdasarkan Penilaian Acuan Patokan (PAP) dengan menggunakan acuan ketuntasan pencapaian tujuan pembelajaran berdasarkan ketuntasan belajar individu dengan menggunakan rumus $N P=\frac{R}{S M} \times 100$ dan untuk menghitung Ketuntasan Belajar klasikal (KBK) Presentase ketuntasan $=\frac{\text { banyaknya siswa yang tuntas }}{\text { banyaknya siswa }} \times 100 \%$. Data Hasil Tingkat Kemampuan Berpikir Kreatif Siswa (TKBKS), untuk mengetahui tingkat berpikir kreatif yang di gunakan peneliti adalah sebagai berikut.

\begin{tabular}{|c|c|}
\hline $\begin{array}{c}\text { Tingkat } \\
\text { kemampuan } \\
\text { Berpikir Kreatif } \\
\text { Siswa (TKBKS) }\end{array}$ & $\begin{array}{c}\text { Karakteristik Tingkat } \\
\text { Kemampuan Berpikir Kreatif } \\
\text { Siswa }\end{array}$ \\
\hline $\begin{array}{l}\text { TKBKS } 4 \\
\text { (Sangat Kreatif) }\end{array}$ & $\begin{array}{l}\text { Siswa mampu menunjukkan } \\
\text { kefasihan, fleksibilitas dan } \\
\text { kebaruan atau kebaruan } \\
\text { fleksibilitas dalam memecahkan } \\
\text { maupun mengajukan soal. }\end{array}$ \\
\hline $\begin{array}{l}\text { TKBKS } 3 \\
\text { ( Kreatif) }\end{array}$ & $\begin{array}{lrr}\text { Siswa } & \text { menunjukkan } & \text { kefasihan } \\
\text { dan fleksibilitas } & \text { dalam } \\
\text { memecahkan } & \text { maupun } \\
\text { mengajukan soal. } & \end{array}$ \\
\hline $\begin{array}{l}\text { TKBKS } 2 \\
\text { (Cukup Kreatif) }\end{array}$ & $\begin{array}{l}\text { Siswa mampu menunjukkan } \\
\text { kebaruan fleksibilitas dalam } \\
\text { memecahkan atau mengajukan } \\
\text { soal. }\end{array}$ \\
\hline
\end{tabular}




\begin{tabular}{|l|l|}
\hline $\begin{array}{c}\text { Tingkat } \\
\text { kemampuan } \\
\text { Berpikir Kreatif } \\
\text { Siswa (TKBKS) }\end{array}$ & \multicolumn{1}{|c|}{$\begin{array}{c}\text { Karakteristik Tingkat } \\
\text { Kemampuan Berpikir Kreatif } \\
\text { Siswa }\end{array}$} \\
\hline TKBKS 1 & Siswa mampu menunjukkan \\
(Kurng Kreatif) & kefasihan dalam memecahkan \\
& maupun mengajukan soal. \\
\hline TKBKS 0 & Siswa tidak mampu \\
(Tidak Kreatif) & menunjukkan aspek indikator \\
& berfikir kreatif \\
\hline
\end{tabular}

Analisis data Hasil angket dengan menggunakan Problem Posing (Pengajuan Soal) mengguankan angket bergradasi atau berperingkat 1 sampai 4 Cara menghitung nilai adalah Jika pernyataan menunjukkan respon positif Rata - rata $=[(4 \times k)+(3 \times k)+(2 \times k)+(1 \times k)]: \mathrm{n}$ Dan jika pernyataan menunjukkan respon negatif Rata - rata $=$ $[(1 \times k)+(2 \times k)+(3 \times k)+(4 \times k)]: n$.

\section{HASIL PENELITIAN}

Temuan penelitian ini akan dibahas sesuai dengan urutan rumusan masalah peneliti pada BAB1 dan rancangan penelitian yang telah di buat sebelumnya.

1. Tes hasil belajar

Siswa dapat dikatakan tuntas apabila mendapatkan skor $\geq 79$ sehingga pada penelitian ini siswa yang tuntas sebanyak 29 dan yang tidak tuntas sebanyak 5 secara klasikal dapat dihitung dengan menggunakan rumus Presentase Ketuntasan $=\frac{\text { banyaknya siswa yang tuntas }}{\text { banyaknya siswa }} \times 100 \%$

Maka diperoleh, Presentase ketuntasan $=\frac{29}{34} \times 100 \%=85,29 \%$

Berdasarkan data ketuntasan kelas secara klasikal bahwa tujuan pembelajaran dikatakan tuntas jika nilai rata - rata klasikal $\geq 85$. Dari data diatas nilai rata rata klasikal diperoleh $85,29 \%$. Maka dapat disimpulkan bahwa secara klasikal tujuan pembelajaran dikatakan tuntas

2. Tingkat Kemampuan Berpikir Kreatif Siswa
Data Tingkat Kemampuan Berpikir Kreatif Siswa (TKBS) diambil dari Tes Hasil Belajar yang dikorelasikan dengan komonen berpikir kreatif sehingga peneliti mampu menganalisis (TKBS) tiap siswa, adapun data dari (TKBS) sebagai berikut

\begin{tabular}{|c|c|}
\hline TKBK & Presentase \\
\hline TKBKS 4 & $=\frac{23}{34} \times 100 \%=67,64=68 \%$ \\
\hline TKBKS 3 & $=\frac{2}{34} \times 100 \%=5,58=6 \%$ \\
\hline TKBKS 2 & $=\frac{6}{34} \times 100 \%=17,64 \%=18 \%$ \\
\hline TKBKS 1 & $=\frac{3}{34} \times 100 \%=8,82 \%=9 \%$ \\
\hline TKBKS 0 & $=\frac{0}{34} \times 100 \%=0 \%$ \\
\hline
\end{tabular}

3. Respon Siswa

Respon siswa diperoleh dari memberikan angket kepada siswa, hasil rata - rata tiap butir pernyataan siswa yaitu, No.1 sebesar 3,51, No.2 sebesar 3,36, No.3 sebesar 3,21, No.4 sebesar 3,18, No.5 sebesar 3,12 , no 6 sebesar 2,90, No.7 sebesar 2,81, No. 8 sebesar 3,21, No.9 sebesar 3,33, No.10 sebesar 3,33 , No. 11 sebesar 3,06, No. 12 sebesar 3,06, No. 13 sebesar 3,06, dan No.14 sebesar 3,24 .

\section{PEMBAHASAN}

1. Hasil penelitian Tes Hasil Belajar

Dari data skor hasil ujian Tes Hasil Belajar (THB) sebanyak 29 atau $85 \%$ siswa yang tuntas sedangkan sebanyak 5 atau $15 \%$ siswa yang tidak tuntas dan tuntas secara klasikal yaitu sebanyak 85,29 \%. Siswa yang tidak tuntas disebabkan beberapa faktor seperti kurang memperhatikan saat guru menerangkan, kurang ada kemauan dalam belajar matematika dan kurangnya komunikasi pada saat kerja kelompok.

2. Hasil Penelitian Tingkat Kemampuan Berpikir Kreatif Siswa

Dari hasil analisis dapat diketahui sebanyak 23 atausekitar $67 \%$ siswa dikategorikan Tingkat 
Kemampuan Berpikir Kreatif Siswa (TKBS) pada posisi sangat kreatif, sebanyak 2 atau sekitar $6 \%$ siswa dikategorikan TKBS pada posisi kreatif, sebanyak 6 atau sekitar $18 \%$ siswa dikategorikan TKBS pada posisi cukup kreatif, sebanyak 3 atau sekitar 9\% siswa dikategorikan TKBS pada posisi kurang kreatif, dan sebanyak 0 atau sekitar $0 \%$ siswa dikategorikan TKBS pada posisi tidak kreatif. Sudah terlihat jelas bahwa presentase TKBKS 4 lebih banyak daripada peresentase TKBKS yang lainya, sehingga dapat disimpulkan bahwa pembelajaran mengunakan Problem Posing (Pengajuan Soal) rata-rata sebagian besar siswa sangat kreatif .

3. Hasil Penelitian Respon Siswa

Data respon siswa Dapat disimpulkan yang terendah adalah butir pernyataan nomor tujuh sebesar 2,81 yang menyatakan bahwa "Saya kurang mengerti materi, saat belajar matematika menggunakan pembelajaran Problem Posing” sedangkan yang tertinggi adalah butir nomor satu sebesar 3,51 yang menyatakan bahwa "Saya merasa model pembelajaran Problem Posing bermanfaat untuk belajar matematika" dengan demikian dapat dikatakan bahwa respon siswa positif..

\section{PENUTUP}

\section{Simpulan}

Berdasarkan hasil analisis dan pembahasan terhadap penelitian yang dilakukan, maka dapat diambil kesimpulan sebagai berikut:

1. Hasil belajar siswa setelah diterapkan pembelajaran matematika materi menyelesaikan masalah sehari hari dengan menggunakan teorema pytagoras dengan menggunakan pendekatan Problem Posing (Pengajuan Soal) di kelas VIII A di SMPN 2 Taman tuntas secara klasikal.

2. Tingkat Kemampuan Berpikir Kreatif Siswa setelah di terapkan pembelajaran matematika materi menyelesaikan masalah sehari - hari dengan menggunakan teorema pytagoras dengan pendekatan Problem Posing (Pengajuan Soal) di kelas VIII A di SMPN 2 Taman sebagain besar siswa mampu berada pada posisi TKBS 4 (Siswa mampu mengaplikasikan 4 komponen berpikir kreatif) yaitu sebesar $67 \%$ sehinggga siswa dapat dikatakan sangat kreatif.

Respon siswa terhadap pelaksanaan pembelajaran matematika materi menyelesaikan masalah sehari - hari dengan menggunakan teorema pytagoras dengan menggunakan pendekatan Problem Posing (Pengajuan Soal) di kelas VIII A di SMPN 2 Taman yang memiliki rata - rata tertinggi adalah "saya merasa model pembelajaran Problem Posing bermanfaat untuk belajar matematika" yaitu sebesar 3,51 sehingga respon siswa dapat dikatakan positif.

\section{Saran}

Dari hasil penelitian ini perangkat pembelajaran matematika menggunakan Problem Posing (Pengajuan Soal) merupakan pembelajaran yang cukup di perhitungkan untuk menggali kretiftas siswa oleh karena itu guru harus lebih jeli dalam pemilihan pembeljaran sehingga pembelajaran di kelas tidak monoton dan tidak membosankan.

\section{DAFTAR PUSTAKA}

Arikunto, Suharsimi. 2010. Prosedur Penenlitian Suatu Pendekatan Praktik.Jogyakarta: RinekaCipta

Arikunto, Suharsimi. 2013. Prosedur Penenlitian Suatu Pendekatan Praktik. Jakarta: PT. Rineka Cipta.

Dimayati dan Mudjono. 2006. Belajar dan Pembelajaran. Jakarta: Rineka Cipta.

DPN.2005. Kamus Besar Bahasa Indonesia EdidiKetiga. Jakarta: Balai Pustaka.

Mulyasa. 2013. Pengembangan dan Implementasi Kurikulum 2013. Bandung. PT Remaja Rosda karya NgalimPurwanto. 2010. Prinsip - PrinsipdanTeknik Evaluasi Pengajaran. Bandung. PT RemajaRosdakarya.

Nurhaini D dkk.2008. Matematika Konsepdan Aplikasinya. Jakarta. JawaPos Group

Sagala, Syaiful. 2010. Konsep dan Makna Pembelajaran. Bandung: Alfabeta. 
Siswono, T.Y.E. 199. 2007. Penjenjangan Kemampuan Berpikir Kreatif dan Identifikasi Prosess Berfikir Kreatif Siswa Dalam Memecahkan dan Mengajukan Masalah Mataematika. Desertasi.Tidak di publikasikan. Surabaya: Pascasarjana Unesa.

Sudjana Nana. 2011. Penilaian Hasil Proses Belajar Mengajar. Bandung. PT RemajaRosdakarya.

Sudjana. 2005. MetodeStatistik. Bandung. PT. Taristo Bandung.
Susanto Ahmad. 2013. Teori Belajar dan Pembelajaran di Sekolah Dasar. Jakarta. Kencana Pernada Media Grup.

Thobroni, M. 2015. Belajar dan Pembelajaran Teori dan Praktik. Yogyakarta: Ar - Ruzz Media.

Trianto. 2007. Model - Model Pembelajaran InovatifProgresif. Jakarta: Kencana

Uno B. Hamzah. 2006. Perencanaan Pembelajaran. Gorontal:Bumiaksara

Yamin Martinis. 2013. Setrategi dan metode Dalam Pembelajaran. Jambi.Refrensi (GP Press). 